\title{
Use of an online e-learning module to standardise the assessment and reporting of a subjective endpoint in a multicentre rct
}

Thomas Pinkney $^{1,3^{*}}$, David Bartlett ${ }^{1}$, Adrian Gheorghe ${ }^{2}$, George Dowswell ${ }^{2,1}$, Dion Morton ${ }^{1,3}$, Melanie Calvert ${ }^{2,1}$

From 2nd Clinical Trials Methodology Conference: Methodology Matters

Edinburgh, UK. 18-19 November 2013

\section{Background}

Multicentre trials employing a subjective primary outcome measure have the potential to suffer from significant interrater variability which may compromise the validity of findings. The primary outcome for the ROSSINI Trial was surgical site infection. We designed a bespoke online training module with embedded quiz to ensure standardisation and reproducibility of wound assessment.

\section{Methods}

We designed an online e-learning module comprising an educational review of surgical site infection signs and symptoms, as well as a quiz with high quality digital photos of surgical wounds to ensure optimal and standardised diagnosis. Automated feedback was given instantly to maximise and reinforce learning.

\section{Results}

The e-learning module and quiz was completed by the majority of local investigators at the 21 sites that opened for the ROSSINI trial. A total of 769 patients were recruited to the trial and each patient underwent at least two blinded wound reviews as part of the primary outcome assessment.

\section{Conclusion}

The online learning resource provided effective training and accreditation to wound reviewers at multiple sites in a convenient and reproducible manner. This adjunct to our trial served to standardise outcome assessment and hopefully reduced inter-observer variability.

West Midlands Research Collaborative, Birmingham, UK

Full list of author information is available at the end of the article

\author{
Authors' details \\ ${ }^{1}$ West Midlands Research Collaborative, Birmingham, UK. ${ }^{2}$ Primary Care \\ Clinical Sciences, University of Birmingham, Birmingham, UK. ${ }^{3}$ Academic \\ Department of Surgery, University of Birmingham, Birmingham, UK.
}

Published: 29 November 2013

doi:10.1186/1745-6215-14-S1-P64

Cite this article as: Pinkney et al:: Use of an online e-learning module to standardise the assessment and reporting of a subjective endpoint in a multicentre rct. Trials 2013 14(Suppl 1):P64.
Submit your next manuscript to BioMed Central and take full advantage of:

- Convenient online submission

- Thorough peer review

- No space constraints or color figure charges

- Immediate publication on acceptance

- Inclusion in PubMed, CAS, Scopus and Google Scholar

- Research which is freely available for redistribution
C Biomed Central 